DOI: https://doi.org/10.24127/ajpm.v9i1.2305

\title{
PENGEMBANGAN PERANGKAT PEMBELAJARAN MATEMATIKA BERBASIS PENDEKATAN CONTEXTUAL TEACHING AND LEARNING TERHADAP KEMAMPUAN KOMUNIKASI MATEMATIS
}

\author{
Yulia Utami Putri ${ }^{1}$, Edwin Musdi ${ }^{2}$, Dony Permana ${ }^{3}$, Yerizon $^{4 *}$ \\ ${ }^{1,2,3,4}$ Fakultas Matematika dan Ilmu Pengetahuan Alam, Universitas Negeri Padang, Indonesia \\ ${ }^{*}$ Corresponding author. Jl. Prof. Dr. Hamka Air Tawar Padang, Sumatera Barat, Indonesia

E-mail: $\frac{\frac{\text { lia.utamiputri18@gmail.com }}{\text { win_musdi@yahoo.co.id }}{ }^{2)}}{\frac{\text { donypermana27@gmail.com }}{\text { yerizon@fmipa.unp.ac.id }}^{\left.{ }^{*}\right)}}$

Received 17 September 2019; Received in revised form 22 December 2019; Accepted 30 March 2020

\begin{abstract}
Abstrak
Penelitian ini bertujuan untuk menghasilkan perangkat pembelajaran matematika berbasis pendekatan contextual teaching and learning (CTL) untuk meningkatkan kemampuan komunikasi matematis peserta didik. Subjek penelitian ini adalah siswa kelas VII SMP 26 Padang denagn 32 siswa. Penelitian ini adalah penelitian pengembangan. Model pengembangan yang digunakan dalam penelitian ini adala model Plomp yang terdiri dari tiga fase yaitu preliminary research, development and prototyping phase, dan assessment phase. Data efektifitas dari perangkat pembelajaran diambil dari tes kemampuan komunikasi matematis peserta didik. Dari hasil tes kemampuan komunikasi matematis diperoleh bahwa rata-rata skor sudah efektif. Persentase ketuntasan klasikal adalah 78,12\% atau lebih dari $75 \%$ dengan nilai rata-rata ketuntasan 76.6. Dengan persentase ketuntasan lebih dari 75\% menunjukkan bahwa tujuan pembelajaran tercapai dan perangkat pembelajaran berbasis CTL secara umum dapat dikatakan efektif dan layak untuk digunakan.
\end{abstract}

Kata kunci: contextual teaching and learning; perangkat pembelajaran; komunikasi matematis.

\begin{abstract}
The purpose of this study is to develop of mathematical learning devices based on the contextual teaching and learning approach in terms of students' mathematical communication skills. The subjects of this study were seventh grade students of SMPN 26 Padang with a total of 32 students. This research includes the type of development research. The development model used in this study is the Plomp model. The Plomp model consists of three phases. They are preliminary research, development or prototyping stage and assessment phase. Data on the effectiveness of learning devices are taken from the results of tests of students' mathematical communication skills. From the test results, it is found that the students' average test scores of mathematical communication skills are effective. The percentage of completeness in classical is $78.12 \%$ or $\geq 75 \%$ with the average value of students who complete is 76.6 which exceeds the minimum completeness. With the percentage of completeness more than $75 \%$ indicates that the learning objectives have been achieved and learning devices in the form of CTL-based that are generally developed are considered to be effective so that they are feasible to use.
\end{abstract}

Keywords: contextual teaching and learning; learning tools; mathematical communication.

\section{PENDAHULUAN}

Matematika memiliki peranan penting dalam perkembangan ilmu pengetahuan, kemajuan teknologi dan keberhasilan program pendidikan. Pembelajaran matematika yang dilaksanakan hendaknya mampu membantu siswa mengkonstruksi pengetahuannya sendiri. Dalam matematika ada beberapa kemampuan yang perlu dikembangkan, yaitu salah satunya kemampuan komunikasi matematis (Susanti, dkk., 2019). Kemampuan komunikasi matematis 
adalah salah satu aspek dari lima aspek dalam kurikulum pendidikan matematika di Indonesia yang penting untuk dikembangkan bagi siswa. Kemampuan komunikasi matematis memegang peranan penting dalam pembelajaran matematika (Suningsih \& Arnidha, 2017).

Seorang siswa yang sudah mampu bernalar dan memecahkan masalah matematika harus mampu untuk mengkomunikasikan hasil pemikiran mereka ke dalam bentuk matematika, model matematika, dan mengekspresikan segala pemikiran mereka secara lisan maupun tulisan dengan baik (Rangkuti, 2014).

Berdasarkan hasil penelitian terdahulu diperoleh bahwa kemampuan komunikasi matematis siswa masih rendah (Setiawati dkk, 2018; Nurida dan Yuniarti, 2018). Hal ini juga sejalan dengan hasil pengamatan di sekolah menengah pertama di Padang menunjukkan bahwa masih banyak siswa yang belum dapat membuat hubungan antara yang mereka pelajari di sekolah dan bagaimana pengetahuan tersebut diaplikasikan serta siswa mengalami kesulitan mengkomunikasikannya.

Rata-rata nilai komunikasi matematis siswa masih kurang. Kemampuan menyampaikan informasi seperti menyatakan ide, mengajukan pertanyaan, dan menanggapi pernyataan/pendapat orang lain. Ini berarti masih terjadi pelaksanaan proses pembelajaran di kelas yang jarang melatihkan dan mengembangkan keterampilan komunikasi dan proses interaksi diantara siswa.

$$
\text { Untuk mengatasi keadaan }
$$

tersebut, perlu dilakukan perubahan mendasar dalam pembelajaran matematika. Salah satunya membuat perangkat pembelajaran yang dapat menunjang keberhasilan peserta didiknya. Perangkat pembelajaran akan mempengaruhi keberhasilan proses pembelajaran di kelas, karena memberikan kemudahan dan dapat membantu guru dalam mempersiapkan dan melaksanakan kegiatan belajar mengajar (Munawarah, 2018).

Selain itu menerapkan model, strategi, ataupuan pendekatan pembelajaran tertentu dapat menjadi solusi permasalahan tersebut. Salah satu pendekatan yang dapat dilakukan oleh guru untuk meningkatkan kemampuan komunikasi matematis siswa adalah dengan pendekatan Contextual Teaching and Learning (CTL). Pembelajaran dengan pendekatan kontekstual adalah suatu konsep pembelajaran yang dapat membantu guru menghubungkan materi pelajaran dengan situasi nyata, dan memotivasi siswa untuk membuat koneksi antara pengetahuan dan penerapannya pada kehidupan sehari-hari (Berns \& Erickson, 2001; Suryawati \& Osman, 2018).

Pendekatan CTL dapat merubah kebiasaan guru sebagai fasilitator menjadi mediator yang aktif dan kreatif dalam meningkatkan kegiatan belajar siswa (Ekowati, Darwis, Upa, \& Tahmir, 2015). CTL memiliki 7 komponen dalam proses pembelajaran yaitu constructivism, questioning, inquiry, learning community, modeling, reflection, dan assessment authentic (Fadillah, dkk., 2017). Komponen tersebut diharapkan akan membuat siswa lebih aktif dalam proses pembelajaran dan akan lebih mudah dalam memahami konsep matematika (Nartani, Hidayat, \& Sumiyati, 2015).

Pendekatan CTL sudah digunakan oleh beberapa peneliti sebelumnya. Susanti (2018) meneliti tentang pengaruh pendekatan CTL ditinjau dari kedisiplinan belajar mahasiswa. 
Mulhamah \& Putrawangsa (2017) meneliti tentang pengaruh $C T L$ terhadap kemampuan pemecahan masalah peserta didik. Dari penelitian tersebut belum ada bahan ajar khusus dengan pendekatan CTL untuk meningkatkan kemampuan komunikasi matematis peserta didik. Untuk itu perlu adanya pengembangan perangkat pembelajaran yang berupa rencana pelaksanaan pembelajaran (RPP) dan lembar kerja peserta didik (LKPD) yang menekankan pada pembelajaran sesuai dengan konteks dunia nyata.

Perangkat pembelajaran berbasis CTL adalah perangkat pembelajaran yang menekankan pada pembelajaran sesuai dengan konteks kehidupan sehari-hari siswa, untuk merealisasikan kurikulum yang tepat dengan tujuan pelaksanaannya dalam pendidikan (Mulhamah \& Putrawangsa, 2017). Sehingga perangkat pembelajaran dengan pendekatan kontekstual ini dianggap efektif karena dalam proses pembelajaran akan memberikan pemahaman yang lebih mendalam. Perangkat dengan pendekatan CTL memungkinkan untuk terciptanya suatu interaksi yang tinggi antara peserta didik dengan guru ataupun peserta didik dengan peserta didik (Rangkuti, 2014). Hal ini dikarenakan pada pendekatan CTL memberikan peluang kepada peserta didik untuk belajar secara kooperatif, bekerjasama dengan teman sejawatnya melalui diskusi, presentasi dan adu argumentasi atas ide-ide yang dimiliki sehingga dapat meningkatkan kemampuan komunikasi matematika siswa (Ratnasari \& Saefudin, 2018). Sehingga, tujuan penelitian ini untuk mengetahui efektivitas perangkat pembelajaran matematika berbasis pendekatan Contextual Teaching and Learning terhadap kemampuan komunikasi matematis siswa.

\section{METODE PENELITIAN}

Penelitian ini merupakan jenis penelitian pengembangan. Model pengembangan yang digunakan adalah model Plomp yang terdiri dari tiga fase, yaitu preliminary research, development or prototyping stage dan assessment phase. Model Plomp mempunyai beberapa kelebihan dalam menilai kepraktisan melalui kegiatan one to one, small group dan field test. Subjek penelitian ini adalah siswa kelas VII SMPN 26 Padang dengan jumlah siswa adalah 32 orang.

Bahan ajar harus memenuhi kriteria valid, praktis dan efektif (Nieveen \& Folmer, 2013). Validitas diperoleh dari hasil validasi oleh para ahli yang berisikan validasi isi, konstruk dan bahasa. Perangkat dikatakan praktis apabila dapat diterapkan oleh guru sesuai dengan yang direncanakan dan mudah untuk dipahami oleh siswa. Sedangkan keefektifan dilihat melalui akivitas saat proses pembelajaran dan hasil belajar.

Instrumen yang digunakan dalam penelitian ini adalah tes kemampuan komunikasi matematis berbentuk esai berjumlah 3 butir soal.

Uji efektivitas dilakukan pada uji lapangan diawali dengan kegiatan pembelajaran menggunakan perangkat pembelajaran berbasis pendekatan $C T L$ dilanjutkan dengan tes kemampuan komunikasi matematis. Lembar jawaban tes tersebut dinilai berdasarkan rubrik penilaian komunikasi matematis kemudian hasil tersebut dianalisis untuk menentukan efektivitas perangkat pembelajaran terhadap kemampuan komunikasi matematis dengan membandingkan hasil tes dengan kriteria ketuntasan minimum. Teknik analisis data yang digunakan adalah statistik deskriptif. 


\section{HASIL DAN PEMBAHASAN}

Pengembangan suatu produk untuk menunjang proses pembelajaran merupakan salah satu alternatif untuk meningkatkan kualitas dari proses pendidikan. Produk yang dikembangkan dalam penelitian ini adalah RPP dan LKPD berbasis pendekatan Contextual Teaching and Learning.

Perangkat pembelajaran yang dirancang akan divalidasi terlebih dahulu oleh para ahli. Perangkat pembelajaran yang telah divalidasi akan diujicobakan pada kegiatan field test sebanyak enam kali pertemuan. Proses pengembangan perangkat pembelajaran matematika berbasis pendekatan contextual teaching and learning pada penelitian ini telah dilakukan melalui tahapan dalam model pengembangan Plomp yaitu preliminary research, development or prototyping stage dan assessment phase yang dimana melalui tahapan-tahapan tersebut dapat diketahui bahwa perangkat pembelajaran yang meliputi rencana pelaksanaan pembelajaran dan lembar kerja peserta didik yang dikembangkan telah memenuhi kriteria validitas, praktikalitas dan efektivitas. Dalam hal ini, yang akan dibahas adalah tentang keefektifan produk yang digunakan terhadap kemampuan komunikasi matematis siswa.

Suatu produk dapat dikatakan efektif atau tidak dalam pembelajaran dapat dilihat dari bagaimana peningkatan hasil belajar dari siswa yang telah diberikan produk tersebut. Salah satu cara untuk dapat melihat efektivitas dari suatu perangkat pembelajaran adalah dengan memberi-kan tes akhir pada siswa. Dalam penelitian ini, untuk melihat efektivitas penggunaan perangkat pembelajaran matematika yang meliputi RPP dan LKPD berbasis pendekatan $C T L$ adalah dari nilai tes kemampuan komunikasi matematis yang akan diberikan pada peserta didik, yang dimana materi yang dipilih dalam penelitian ini adalah materi tentang bangun datar segiempat dan segitiga. Uji efektivitas ini dilakukan setelah semua pertemuan telah selesai dilakukan pada tahap uji lapangan.

Field test dilakukan di kelas VII.1 dengan jumlah siswa yang mengikuti pembelajaran sebanyak 32 orang siswa yang terdiri dari 17 orang laki-laki dan 15 orang perempuan yang dibagi dalam 6 kelompok dengan masing-masing kelompok memiliki 5 sampai 6 anggota dan dikelompokkan secara heterogen.

Pada proses pembelajaran, setiap kelompok yang telah ditentukan masing-masing akan mendapatkan lembar kerja peserta didik yang dirancang dengan memuat semua komponen dari pembelajaran dengan pendekatan CTL yaitu constructivism, questioning, inquiry, learning community, modelling, reflection, dan assessment authentic yang akan dikerjakan melalui diskusi kelompok.

Dalam kegiatan diskusi tersebut siswa akan diberikan kesempatan untuk dapat bekerjasama dan memberi kesempatan kepada siswa untuk dapat mengeluarkan pendapatnya serta dapat mendengarkan pendapat dari setiap anggota kelompok, hal tersebut akan merangsang dalam hal komunikasi matematis mereka. Setelah proses diskusi selesai, maka hasil diskusi dari lembar kerja peserta didik tersebut akan dipresentasikan oleh salah satu kelompok yang dipilih secara acak oleh pendidik dan akan dilakukan secara bergantian oleh kelompok lainnya pada setiap pertemuan. Di akhir pembelajaran, akan diukur kemampuan komunikasi matematis siswa dengan menggunakan soal tes kemampuan 
komunikasi matematis yang telah di validasi oleh para ahli dan telah memenuhi kriteria validitas.

Efektifitas penggunaan perangkat pembelajaran matematika yang meliputi RPP dan LKPD dengan pendekatan CTL dilihat dari nilai tes kemampuan komunikasi matematis peserta didik. Data uji coba tes kemampuan komunikasi matematis diperoleh dengan cara mengujikan 3 butir soal essay untuk materi segiempat (persegi panjang, belah ketupat dan trapesium) serta segitiga. Uji efektivitas ini dilakukan setelah semua pertemuan telah selesai dilakukan pada tahap uji lapangan. Hasil kemampuan komunikasi matematis siswa kelas VII 1 disajikan pada Tabel 1.

Tabel 1. Persentase ketuntasan peserta didik.

\begin{tabular}{cccc}
\hline & \multicolumn{2}{c}{ Ketuntasan } & \multirow{2}{*}{ Total } \\
\cline { 2 - 3 } & $\begin{array}{c}\text { Tuntas } \\
(\geq \mathbf{6 8})\end{array}$ & $\begin{array}{c}\text { Tidak Tuntas } \\
(<\mathbf{6 8})\end{array}$ & \\
\hline Jumlah Peserta Didik & 25 & 7 & 32 \\
Rata-rata Nilai & 76,6 & 56,6 & \\
Persentase Ketuntasan & $78,12 \%$ & $21,88 \%$ & 100 \\
\hline
\end{tabular}

Tabel 1 menunjukkan bahwa persentase peserta didik yang tuntas dalam tes kemampuan komunikasi matematis ini sebesar $78,12 \%$ atau $\geq$ $75 \%$ dari 32 orang siswa yang mengikuti tes dan sebesar $21,88 \%$ dari 32 siswa yang tidak tuntas dalam tes kemampuan komunikasi matematis. Dari hasil tes kemampuan komunikasi matematis diperoleh rata-rata nilai dari 32 siswa adalah 72 . Hal tersebut berarti bahwa rata-rata nilai tes kemampuan komunikasi matematis siswa kelas VII.1 berkategori efektif. Berdasarkan persentase tes kemampuan komunikasi matematis dari 32 siswa, maka dapat ditentukan jumlah siswa yang mencapai nilai ketuntasan $\geq 68$ sebanyak 25 siswa dengan rata-rata nilai yang diperoleh adalah 76,6. Sedangkan siswa yang memperoleh nilai kurang dari kriteria ketuntasan minimal atau $\leq 68$ sebanyak 7 siswa dengan rata-rata nilai yang diperoleh adalah 56,6.

Berdasarkan hasil penelitian ini, maka dapat disimpulkan bahwa pada kelas VII, perangkat pembelajaran yang dikembangkan telah memenuhi kriteria keefektifan ditinjau dari kemampuan komunikasi matematis yaitu persentase ketuntasan secara klasikal sudah mencapai $78,12 \%$ atau $\geq 75 \%$ dengan nilai rata-rata siswa yang tuntas adalah 76,6 yang telah mencapai kriteria ketuntasan minimum yang telah ditetapkan yaitu sebesar 68. Hal ini menunjukkan bahwa siswa telah memiliki pemahaman yang baik terhadap materi yang disajikan dengan menggunakan perangkat pembelajaran berbasis pendekatan CTL ini.

Dengan persentase ketuntasan yang lebih dari $75 \%$ menunjukkan bahwa tujuan pembelajaran telah tercapai dan produk yang dikembangkan secara umum dinilai telah efektif sehingga layak untuk digunakan.

Keberhasilan yang terjadi disebabkan karena perangkat pembelajaran matematika berbasis CTL ini dapat menjadikan siswa lebih aktif dan termotivasi dalam proses pembelajaran 
karena materi yang disajikan adalah materi yang dapat ditemukan dalam kehidupan sehari-hari siswa. Namun, masih terdapat siswa yang tidak tuntas dalam tes kemampuan komunikasi matematis, hal ini disebabkan karena siswa tersebut masih mengalami kesulitan dalam mengubah soal cerita kedalam bentuk model matematika, siswa juga masih kesulitan dalam menjelaskan ide situasi dan relasi matematika secara tulisan dengan gambar. Hal lain yang membuat nilai siswa tersebut dibawah kriteria ketuntasan minimal karena ada beberapa siswa yang tidak mengikuti proses pembelajaran karena tidak hadir dan baru hadir saat diadakan tes kemampuan komunikasi matematis diakhir pertemuan.

$$
\text { Perangkat pembelajaran }
$$

matematika berbasis pendekatan contextual teaching and learning yang dihasilkan telah memenuhi kriteria efektif. Hal ini dikarenakan dengan menerapkan perangkat pembelajaran yang memuat rencana pelaksanaan pembelajaran dan lembar kerja peserta didik berbasis pendekatan contextual teaching and learning menunjukkan bahwa siswa lebih aktif dalam proses pembelajaran, siswa aktif dalam memecahkan permasalahan yang ada, siswa berusaha untuk menyusun pengetahuannya sendiri dan berusaha untuk dapat membuat kesimpulan dari berbagai masalah yang telah mereka pecahkan secara berkelompok, hal tersebut terlihat dari hasil observasi yang dilakukan pada setiap proses pembelajaran.

$$
\text { Pembelajaran menggunakan }
$$

pendekatan $C T L$ dapat menciptakan suatu interaksi yang tinggi antara peserta didik dengan guru ataupun peserta didik dengan peserta didik.Hal ini dikarenakan pada pendekatan CTL memberikan peluang kepada peserta didik untuk belajar secara kooperatif, bekerjasama dengan teman sejawatnya melalui diskusi, presentasi dan adu argumentasi atas ide-ide yang dimiliki sehingga dapat meningkatkan kemampuan komunikasi matematika siswa. Penelitian ini sejalan dengan penelitian Berns \& Erickson (2001); Suryawati \& Osman (2018); Ekowati, Darwis, Upa, \& Tahmir (2015); Nartani, Hidayat, \& Sumiyati (2015); Mulhamah \& Putrawangsa (2017) bahwa CTL baik digunakan untuk pembelajaran.

\section{KESIMPULAN DAN SARAN}

Berdasarkan hasil penelitian dan pembahasan dalam penelitian ini, dapat disimpulkan bahwa perangkat pembelajaran matematika berbasis pendekatan Contextual Teaching and Learning yang terdiri dari RPP dan LKPD memenuhi kategori efektif terhadap kemampuan komunikasi matematis peserta didik. Hal ini menunjukkan bahwa siswa telah memiliki pemahaman yang baik terhadap materi yang disajikan dan dapat meningkatkan kemampuan komunikasi matematis peserta didik dengan menggunakan perangkat pembelajaran berbasis pendekatan Contextual Teaching and Learning ini.

Saran untuk penelitian lebih lanjut yaitu perangkat pembelajaran berbasis CTL ini perlu diuji untuk mengukur variabel terikat yang lainnya seperti hasil belajar, kemampuan pemahaman konsep, dan lain sebagainya.

\section{DAFTAR PUSTAKA}

Berns, R., \& Erickson, P. (2001). Contextual Teaching And Learning: Preparing Students For The New Economy. The Highlight Zone Research 1 (5), 1 - 8. 
Ekowati, C. K., Darwis, M., Upa, H. M. D. P., \& Tahmir, S. (2015). The Application Of Contextual Approach In Learning Mathematics To Improve Students Motivation At SMPN 1 Kupang. International Education Studies, 8(8), 81-86. https://doi.org/10.5539/Ies.V8n8p81

Fadillah, A., Dewi, N. P. L. C., Ridho, D., Majid, A. N., \& Prastiwi, M. N. B. (2017). The effect of application of contextual teaching and learning (CTL) model-based on lesson study with mind mapping media to assess student learning outcomes on chemistry on colloid systems. International Journal of Science and Applied Science: Conference Series, 1(2), $101-108$.

Mulhamah, M., \& Putrawangsa, S. (2017). Penerapan Pembelajaran Kontekstual Dalam Meningkatkan Kemampuan Pemecahan Masalah Matematika. Jurnal Pendidikan Matematika, 10 (1), 59- 80. https://doi.org/10.22342/JPM.10.1 .3279.58-80

Munawarah, M. (2017). Pengembangan Perangkat Pembelajaran Matematika Dengan Menggunakan Pendekatan Kontekstual. Mapan: Jurnal Matematika dan Pembelajaran 5(2), $168 \quad-\quad 186$. https://doi.org/10.24252/Mapan.V $5 \mathrm{n} 2 \mathrm{a} 2$

Nartani, C. I., Hidayat, R. A., \& Sumiyati, Y. (2015). Communication In Mathematics Contextual. International Journal Of Innovation And Research In Educational Science s 2(4), 284 287.
Nieveen, N., \& Folmer, E. (2013). Formative Evaluation In Educational Design Research. Educational Design Research. Part A: An Introduction.

Nurida, P., \& Yuniarti, T. (2018). Pengaruh Model Pembelajaran Inkuiri Terbimbing dalam Meningkatkan Kemampuan Komunikasi Matematis Siswa. Jurnal Pendidikan Matematika Unila, 6(1), 89 99-

OECD. (2016). Oecd Factbook 2015/2016- Economic, Environmental and Social Statistics. In OECD Publishing. https://doi.org/10.1787/Factbook2015-En

Rangkuti, D. (2014). Meningkatkan Kemampuan Komunikasi Matematis Siswa Melalui Pendekatan Open-Ended Pada Pembelajaran Matematika Di Kelas VIII SMP Pembangunan Nasional Pagar Merbau. Kultura, 15(1), 4596 - 4602.

Ratnasari, S. F., \& Saefudin, A. A. (2018). Efektivitas Pendekatan Contextual Teaching And Learning (CTL) Ditinjau Dari Kemampuan Komunikasi Matematika Siswa. Mapan 6(1), $119 \quad-\quad 128$ https://doi.org/10.24252/Mapan.2 018v6n1a11

Setiawati, R., Netriwati, \& Nasution, S. P. (2018) Desain Model Pembelajaran Gerla ch Dan Ely Yang Berciri Nilai-Nilai KeIslaman untuk Meningkatkan Kemampuan Komunikasi Matematis. AKSIOMA:Jurnal Program Studi Pendidikan Matematika, 7 (3), 371-379. 
DOI: https://doi.org/10.24127/ajpm.v9i1.2305

Suningsih, A \& Arnidha, Y. (2017)

Komunikasi Matematis Siswa

Tunarungu Menggunakan Model

Pembelajaran Think Pair Share,

AKSIOMA:Jurnal Program Studi

Pendidikan Matematika, 6 (3), 375 - 384.

Suryawati, E., \& Osman, K. (2018). Contextual learning: Innovative approach towards the development of students' scientific attitude and natural science performance. Eurasia Journal of Mathematics, Science and Technology Education, 14(1), $61-76$.

Susanti, V. D., Lusiana, R. L., \& Andari, T. (2019). Pengaruh Project Based Learning Berbasis Media Interaktif Terhadap Kemampuan Komunikasi Matematis Mahasiswa. AKSIOMA: Jurnal Program Studi Pendidikan Matematika, 8(3), 354 - 361. 